\title{
USULAN TATA LETAK GUDANG DENGAN METODE SHARED STORAGE DI PT. AGILITY INTERNATIONAL CUSTOMER PT. HERBALIFE INDONESIA
}

\author{
Erna Mulyati ${ }^{1}$, Irpan Numang ${ }^{2}$, Muchamad Aditya Nurdiansyah ${ }^{3}$ \\ ${ }^{1}$ D4 Logistik Bisnis, Politeknik Pos Indonesia \\ email: ernamulyati@poltekpos.ac.id \\ ${ }^{2}$ D4 Logistik Bisnis, Politeknik Pos Indonesia \\ email: irpannumang15@poltekpos.ac.id \\ ${ }^{3}$ D4 Logistik Bisnis, Politeknik Pos Indonesia \\ email: muchamadaditya35@gmail.com
}

\begin{abstract}
ABSTRAK
PT. Agility International Pondok Ungu Site merupakan salah satu perusahaan 3PL yang bergerak dibidang pergudangan dan transportasi. Perusahaan mempunyai beberapa customer untuk bidang pergudangan, salah satu customer yang bekerja sama adalah PT. Herbalife Indonesia. Saat ini, Salah satu permasalahan yang muncul adalah penempatan produk yang random sering kali membuat picker mengalami lamanya proses picking dan kesalahan pengambilan barang. Metode usulan dalam mengatasi permasalahan tersebut dengan melakukan perbaikan tata letak gudang menggunakan metode shared storage. Perbaikan ini menjadikan proses penempatan produk dengan menyusun area-area penyimpanan berdasarkan kondisi luas lantai gudang. Penempatan barang diurutkan mulai dari produk yang memiliki assignment paling besar hingga produk yang memiliki assignment paling kecil. Shared storage melakukan proses pengelompokan produk untuk disimpan pada rak menggunakan prinsip First in First out (FIFO) dan setiap produk digabungkan menjadi 1 bagian sesuai tingkat aktivitasnya. Berdasarkan hasil perhitungan yang dilakukan, barang yang mempunyai assignment tertinggi harus ditempatkan pada rak pertama atau terdekat dari pintu (I/O) dimana total jarak tempuh untuk seluruh produk yang ada digudang dengan total jarak sebesar $203.6 \mathrm{~m}$, hal ini memudahkan picker dalam proes picking dimana penempatan sebelumnya tidak diketahui total jarak tempuh dari seluruh produk yang ada digudang.
\end{abstract}

Kata Kunci: Tata Letak Gudang, Shared Storage, Picker, Picking

\section{PENDAHULUAN}

Gudang adalah tempat penyimpanan sementara dan pengambilan inventory untuk mendukung kegiatan operasi bagi proses operasi berikutnya, ke lokasi distribusi, atau kepada konsumen akhir (Martono, 2015: 343). Kebutuhan adanya gudang untuk menunjang aktivitas logistik atau aktivitas perusahaan menyebabkan perlu adanya sistem yang mendukung. Pergudangan memiliki peranan penting dimana berfungsi sebagai tempat penyimpanan barang untuk produksi atau hasil produksi dalam rentang waktu tertentu. Gudang sebagai tempat penyimpanan barang setengah jadi, barang bahan baku, barang suku cadang, dan barang produk jadi harus membedakan perlakuan dalam menangani barang - barang tersebut. Penanganan produk perlu dijalankan, termasuk dalam menangani produk consumer goods seperti PT. Agility International. Perusahaan sebagai penyedia jasa 3PL dalam bidang pergudangan, mempunyai beberapa customer yang menggunakan jasanya. Salah satu customer yang menggunakan jasa perusahaan adalah PT. Herbalife Indonesia.
PT. Agility International mempunyai peranan penting dalam kegiatan proses gudang dan pengiriman distribusi produk customer secara cepat dan tepat. Gudang harus dirancang agar produk dapat mengisi kapasitas ruang secara maksimal baik secara vertikal maupun horizontal. Pengelolaan gudang dengan baik perlu adanya sistem yang dapat dibangun dan dikendalikan dengan baik. Sistem pergudangan yang baik adalah sistem pergudangan yang mampu memanfaatkan ruang untuk penyimpanan secara efektif agar dapat meningkatkan utilisasi ruang serta meminimalisasi jarak atau biaya material handling (Heragu, 2008). Perusahaan sebagai penyedia pelayanan pergudangan harus dapat mengelola bisnisnya dengan baik untuk memenuhi kebutuhan konsumen dan harus memiliki pengelolaan tata letak gudang yang baik demi mendukung aktivitas dalam gudang. Pengertian vertical dan horizontal ialah produk harus terisi dalam rak merata kesamping maupun menumpuk keatas agar tidak ada ruang yang kosong. Tata letak adalah sebagai salah satu permasalahan yang dapat selalu terjadi pada aktivitas 
gudang. Perusahaan dengan produktivitas tinggi dituntut untuk mampu melaksanakan proses penerimaan, penyimpanan, pengeluaran barang dengan cepat dan tepat. Proses dalam gudang mempunyai peranan penting dalam berlangsungnya aktivitas selanjutnya.

Perusahaan melakukan penyimpanan produk ke lokasi rak setelah proses inbound dengan penentuan lokasi secara random atau dengan menyimpan produk secara acak. Penempatan produk secara acak dilakukan setelah ada barang yang keluar lalu di isi oleh produk baru. Aktivitas penyimpanan produk sering terkendala oleh lokasi yang belum diketahui, oleh karena itu produk sering disimpan terlebih dahulu dalam lorong antar rak. Produk yang disimpan di lantai lorong dapat mengganggu aktivitas picking dan kurang efektif. Sistem random pada lokasi produk juga sering kali membuat seorang picker bekerja tidak efisien pada saat pengambilan produk. Penelitian lain menjelaskan bahwa penyimpanan barang yang tidak teratur menyebabkan terjadinya penambahan waktu kerja (lembur) staf gudang untuk merapikan serta mendata barang-barang yang masuk dan keluar dari gudang tersebut (Mulyati dan Rachmi, 2012). Untuk itu perlu dilakukan penataan lokasi penyimpanan produk pada gudang dengan menggunakan metode shared storage.

Penelitian yang telah dilakukan Sutisna dan Irfan (2015) Shared Storage yaitu dengan menyusun area-area penyimpanan berdasarkan kondisi luas lantai gudang, kemudian di urutkan area yang paling dekat sampai area yang terjauh dari pintu keluar masuk (I/O) sehingga penempatan barang yang akan segera dikirim diletakan pada area yang paling dekat dan begitu seterusnya. Hasil dari metode shared storage dapat di ketahui materialmaterial yang harus di letakan dekat pintu masuk atau keluar (I/O) sesuai dengan kebutuhan ruang berdasarkan Troughput dan Assigment. Penelitian yang dilakukan (Zaenuri, 2015) menjelaskan kebutuhan ruang yang diperlukan untuk metode shared storage berkisar antara kebutuhan ruang untuk metode randomized storage dan dedicated storage tergantung dari banyaknya informasi yang tersedia mengenai level persediaan selama kurun waktu tertentu. Penelitian yang dilakukan Setiadi dan Iqbal (2015) menghasilkan peta aliran proses, untuk total dari usulan perbaikan waktu peta aliran proses adalah 1 jam 40 menit 21 detik, sehingga jika dibandingkan dengan waktu proses penyimpanan sebelumnya yang mencapai waktu 1 jam 45 menit 6 detik. Hal ini dapat menghemat waktu sebanyak 4 menit 45 detik. Penelitian terkait usulan perbaikan tata letak dengan karakteristik barang yang berbeda dengan penelitian sebelumnya. Barang yang dipakai dengan satuan pcs, pallet, dan disimpan di rak yang sudah ada. Tujuan penelitian ini adalah bagaimana perbaikan tata letak penempatan barang untuk meminimumkan jarak pemindahan dengan menggunakan metode shared storage.

\section{METODE PENELITIAN}

Metode yang akan digunakan pada penelitian ini yaitu menggunakan metode shared storage untuk mendukung aktivitas yang ada di gudang. Metode shared storage merupakan metode yang menyusun area-area penyimpanan berdasarkan kondisi luas lantai gudang, kemudian di urutkan area yang paling dekat sampai area yang terjauh dari pintu keluar masuk (I/O) sehingga penempatan barang yang akan segera dikirim diletakan pada area yang paling dekat dan begitu seterusnya. Hasil identifikasi dan analisis berupa penentuan lokasi produk untuk mempermudah aktivitas di gudang. Adapun langkah - langkah yang dilakukan dalam penyelesaian masalah adalah sebagai berikut:
a. Pengumpulan Data Jumlah Rata-rata Barang Keluar Gudang
b. Pengumpulan Data Jumlah Rata-rata Barang Masuk ke Gudang
c. Kebutuhan Ruang (Space Requirement)
d. Penentuan Lebar Aisle
e. Perhitungan Troughput
f. Perhitungan Assignment
g. Jarak dari Area Gudang ke Pintu
h. Perbandingan Jarak Tempuh Layout Usulan 1 dengan Layout Usulan 2
i. Final Layout

\section{Pengumpulan Data}

Dalam mendapatkan data informasi, maka digunakan beberapa cara, yaitu diantaranya:

a. Studi Lapangan

Pengumpulan data dalam studi lapangan memiliki cara, adapun cara dalam pengumpulan data adalah sebagai berikut:

- Metode Observasi

Pada metode ini dilakukan dengan memahami pengetahuan dari sebuah fenomena, berdasarkan dari pengetahuan yang sudah dimiliki sebeleumnya. Metode ini dilakukan secara langsung terjun ke lapangan agar memahami keadaan yang sebenernya dengan menggunakan indera penglihatan dan melihat langsung proses bisnis yang terjadi di area gudang.

- Metode Dokumentasi

Dokumentasi adalah proses pencatatan dari dokumen atau arsip yang ada pada PT Agility International customer Herbalife Indonesia, khususnya data yang berhubungan dengan masalah pada penelitian.

b. Studi Kepustakaan

Pada metode ini dilakukan melalui studi kepustakaan dari jurnal, buku - buku, skripsi, artikel, dan lainnya yang sudah ada sebelumnya dengan tujuan 
mendapatkan data yang berhubungan dengan judul tugas akhir yang diambil penulis.

\section{Pengolahan Data}

a. Pengumpulan Data Jumlah Rata-rata Barang Keluar Gudang

Langkah pertama mengetahui rata-rata barang keluar per bulan. Hal ini dugunakan untuk mengukur ratarata jumlah barang yang keluar yang ada agar bisa mengetahui barang mana yang sering keluar gudang. Pengeluaran barang perbulan $=\frac{\sum \text { Pengeluaran barang bulan } 1,2,3}{3}$

b. Pengumpulan Data Jumlah Rata-rata Barang Masuk ke Gudang

Langkah kedua mengetahui rata-rata barang masuk ke gudang per bulan, hal ini digunakan untuk megukur rata-rata jumlah barang masuk ke gudang.

Pemasukan barang perbulan $=\frac{\sum \text { Pemasukan barang bulan 1,2,3 }}{3}$

c. Kebutuhan Ruang (Space Requirement)

Kebutuhan dalam penempatan ruang dalam barang sangatlah penting, dikarenakan untuk menentukan seberapa besar atau banyak area untuk barang agar bisa ditampung oleh gudang.

Kebutuhan Ruang $=\frac{\text { Rata-rata Penyimpanan }}{\text { Barang yang ditampung }}$

d. Penentuan Lebar Aisle

Aisle dimanfaatkan sebagai gang atau jalur pergerakan barang, adapun material handling yang digunakan adalah forklift. Penentuan luas gang yang diperlukan berdasarkan dimensi terpanjang yaitu diagonal yang ada pada forklift saat membawa barang. Dengan mengetahui aisle ini, kita dapat mengukur lebar gang/jalur yang akan dilalui oleh forklift.

Diagonal $=\sqrt{(\text { Panjang })^{2}+(\text { Lebar })^{2}}$

e. Perhitungan Troughput

Troughput (T) adalah pengukuran aktivitas atau penyimpanan yang sifatnya dinamis. Aktifitas ini menunjukan banyaknya pergerakan barang atau material baik barang itu keluar maupun barang itu masuk.

$\mathrm{T}=\frac{\text { Rata-rata Barang Masuk }}{\text { Jumlah Kemasan dalam } 1 \text { pallet }}+\frac{\text { Rata-rata Barang Keluar }}{\text { Jumlah Kemasan dalam 1 pallet }}$

\section{f. Perhitungan Assignment}

Perhitungan Assignment dilakukan agar kita dapat mengetahui prioritas penempatan barang sesuai dengan area, dilihat dari banyaknya aktivitas yang ada dan dibandingkan dengan kebutuhan ruang.

Assignment $=\frac{\mathrm{T}}{\mathrm{S}}$

Keterangan:

$\mathrm{T}=$ Troughput

$\mathrm{S}=$ Space Requirement

g. Jarak dari Area Gudang ke Pintu
Jarak tempuh antara barang adalah mulai dari pintu (I/O) menuju ke area penyimpanan. Perhitungan jarak dilakukan dengan menggunakan metode yaitu:

\section{Rectilinier Distance}

Jarak diukur sepanjang lintasan menggunakan garis tegak lurus (orthogonal) satu dengan yang lainnya sebagai contoh adalah barang yang berpindah sepanjang gang aisle pada gudang.

Rectilinier Distance:

$\operatorname{Dij}=\sqrt{(x-a)^{2}+(y-b)^{2}}$

h. Perbandingan Jarak Tempuh Layout Usulan 1 dengan Layout Usulan 2

Setelah diperoleh hasil jarak tempuh material handling layout usulan 1 dan layout usulan 2, maka dilakukan perbandingan untuk mengetahui selisih antara layout usulan 1 dan layout usulan 2. Perhitungan ini dilakukan untuk mencari jarak total terpendek untuk seluruh barang yang ada di gudang.

\section{i. Final Layout}

Final Layout merupakan gambaran yang sebenernya dari pada layout yang direncanakan.

\section{HASIL DAN PEMBAHASAN}

a. Menentukan Rata-Rata Barang Masuk

Menentukan jumlah rata-rata barang yang masuk perbulan dengan rumus:

Barang masuk perbulan $=\frac{\sum \text { Pemasukan barang bulan } 1,2,3}{3}$

Contoh perhitungan: NUTRITIONAL SHAKE MIX FRENCH VANILLA

Barang masuk perbulan $=\frac{21,794}{3}=7.264,66$ dibulatkan menjadi 7.265 karton.

b. Menentukan Rata-Rata Barang Keluar

Menentukan jumlah rata-rata barang yang keluar perbulan adalah dengan rumus:

Barang pengeluaran perbulan $=\frac{\sum \text { Pengeluaran barang bulan 1, 2,3 }}{3}$

Perhitungan barang-barang yang masuk adalah sebagai berikut:

Contoh perhitungan: NUTRITIONAL SHAKE MIX FRENCH VANILLA

Barang keluar perbulan $=\frac{16,200}{3}=5.400$ Karton.

c. Kebutuhan Ruang

Kebutuhan Ruang adalah proses penghitungan untuk setiap produk yang akan disimpan pada gudang, dapat diketahui 1 rak bisa menampung 70 pallet dan isi dari 1 palet itu beragam tergantung jenis dan ukuran barang. Setiap barang yang sudah diketahui hasil nantinya akan dibagi 70 untuk mengetahui kebutuhan ruang setiap produknya. Setelah mengetahui hal tersebut, maka kita 
dapat menghitung untuk mencari nilai dari kebutuhan ruang.

Kebutuhan Ruang $=\frac{\text { Rata-rata penyimpanan }}{\text { Barang yang ditampung }}$

Contoh perhitungan: NUTRITIONAL SHAKE MIX FRENCH VANILLA

Kebutuhan ruang $=\frac{7.265}{50}=145,3$ dibulatkan menjadi 145 pallet. Sehingga membutuhkan 3 ruang.

\section{d. Penentuan Lebar Aisle}

Aisle merupakan gang atau lorong antara rak dengan rak, lorong tersebut digunakan untuk lewatnya MHE (Material Handling Equipment) dan tempat awal penurunan atau penaikan barang ke rak. Adapun MHE yang digunakan ialah Forklift reach truck, Electric pallet truck, hand pallet, dan sejenisnya. Berikut merupakan rumus penentuan lebar aisle:

Diagonal

$$
\begin{aligned}
& =\sqrt{(\text { Panjang })^{2}+(\text { Lebar })^{2}} \\
& =\sqrt{(2)^{2}+(1)^{2}} \\
& =2,2 \mathrm{~m}
\end{aligned}
$$

e. Perhitungan Throughput

Throughput adalah perhitungan pengukuran aktivitas atau penyimpanan yang sifatnya dinamis, aktivitas ini menentukan banyaknya pergerakan barang atau material baik barang itu keluar ataupun barang itu masuk.

$\mathrm{T}=\frac{\text { Rata- rata barang masuk }}{\text { Jumlah kemasan dalam } 1 \text { pallet }}+\frac{\text { Rata- rata barang keluar }}{\text { Jumlah kemasan dalam 1 pallet }}$ Contoh perhitungan: NUTRITIONAL SHAKE MIX FRENCH VANILLA $\mathrm{T}=\frac{7.265}{50}+\frac{5.400}{50}=253,3$ dibulatkan menjadi 253 .

f. Perhitungan Assignment (Penempatan Produk)

Penempatan produk adalah penempatan yang dilakukan agar kita dapat mengetahui prioritas penempatan material sesuai dengan area, dilihat dari banyaknya aktivitas yang ada dan dibandingkan dengan kebutuhan ruang. Perhitungan penempatan produk dapat dilakukan menggunakan cara berikut ini:

Assignment $=\frac{\mathrm{T}}{\mathrm{S}}$

Keterangan:

$\mathrm{T}=$ Throughput

$\mathrm{S}=$ Space Requirement

Contoh perhitungan: NUTRITIONAL SHAKE MIX FRENCH VANILLA

Assignment $=\frac{253}{3}=84,3$ dibulatkan menjadi 84

Berdasarkan hasil perhitungan assignment diatas, maka didapatkan perhitungan akhir untuk menentukan lokasi setiap produk yang akan disimpan pada gudang. Penentuan penyimpanan berdasarkan hasil assignment yang terbesar hingga terkecil untuk penyimpanan yang terdekat dengan pintu (I/O). Data diatas dapat digunakan untuk menentukan tata letak area gudang usulan berdasarkan hasil perhitungan yang sudah dilakukan. Penentuan usulan tata letak dilakukan untuk penempatan penyimpanan produk secara berkelompok atau tidak dilakukan penyimpanan secara acak. Penulis akan membuat 2 layout usulan, guna sebagai pembanding layout manakah yang terbaik untuk penerapannya.

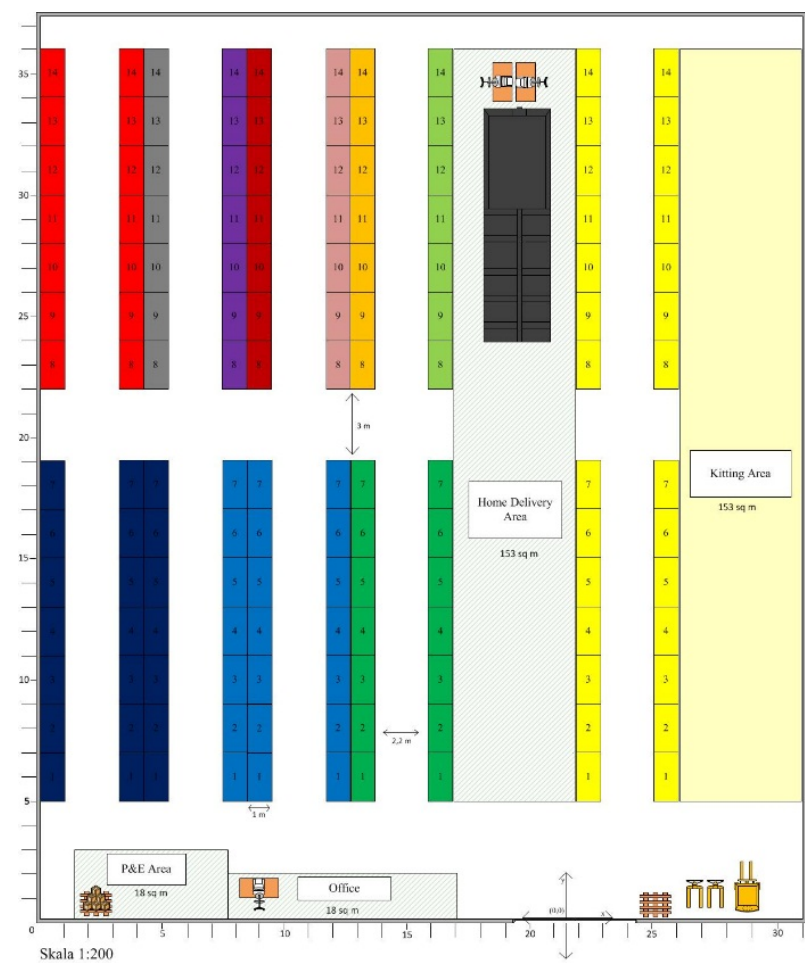

Gambar 1 Layout Usulan 1 Perbaikan Gudang Herbalife 


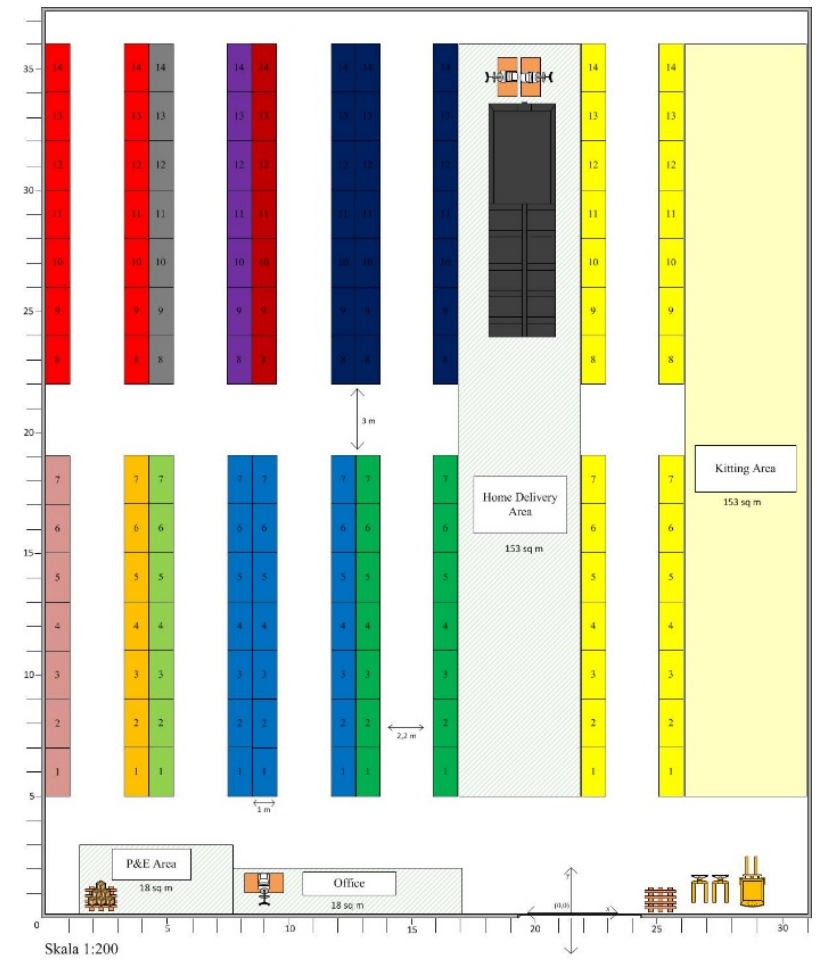

Gambar 2 Layout Usulan 2 Perbaikan Gudang Herbalife

Berdasarkan gambar diatas, pada layout usulan 1 penulis menyimpan produk DUTCH CHOCOLATE yang berwarna hijau muda pada lokasi rak terdepan dekat dengan pintu (I/O). Penempatan produk dilakukan berdasarkan assignment yang ada dan kebutuhan ruang untuk setiap produknya. Pada layout usulan 2 penulis melakukan perubahan pada produk FRENCH VANILLA yang berwarna biru tua. Produk disimpan berada diatas karena jarak rak hampir sama dengan sebelumnya, tetapi untuk produk lainnya mengalami perubahan. Penempatan produk selanjutnya bedasarkan assignment, assignment tertinggi disimpan di rak terdekat dengan pintu (I/O). Berdasarkan hasil layout yang sudah diketahui, selanjutnya perhitungan jarak rak ke pintu (I/O).

g. Jarak Area Penyimpanan ke Pintu Setelah Menggunakan Metode Shared Storage

Penentuan jarak penyimpanan barang didalam gudang dihitung mulai dari area pintu. Pintu sebagai tempat pertama pada saat masuknya barang ketika inbound untuk disimpan kedalam gudang, perhitungan jarak dilakukan dengan rumus rectilinear distance. Jarak diukur dari satu area penyimpanan material ke pintu masuk, Rumus yang digunakan:

$\operatorname{dij}=\sqrt{(x-a)^{2}+(x-b)^{2}}$

Keterangan:

$\operatorname{dij}=$ jarak antara pintu ke area

$\mathrm{x}=$ nilai sumbu $\mathrm{x}$

a $=$ nilai jarak terhadap sumbu $\mathrm{x}$

$\mathrm{y} \quad=$ nilai sumbu $\mathrm{y}$ b

$=$ nilai jarak terhadap sumbu y

Contoh perhitungan pada layout usulan 1:

NUTRITIONAL SHAKE MIX - FRENCH VANILLA

$\operatorname{dij}=\sqrt{(x-a)^{2}+(y-b)^{2}}$

$\operatorname{dij}=\sqrt{(x-16.6)^{2}+(y-5)^{2}}$

$\operatorname{dij}=\sqrt{(275.5)+(25)}$

$\operatorname{dij}=\sqrt{300.5}=17.3 \mathrm{~m}$

Contoh perhitungan pada layout usulan 2:

NUTRITIONAL SHAKE MIX - FRENCH VANILLA

$\operatorname{dij}=\sqrt{(x-a)^{2}+(y-b)^{2}}$

$\operatorname{dij}=\sqrt{(\mathrm{x}-5)^{2}+(\mathrm{y}-22)^{2}}$

$\operatorname{dij}=\sqrt{(25)+(484)}$

$\operatorname{dij}=\sqrt{509}=22.6 \mathrm{~m}$

Berdasarkan hasil perhitungan area penyimpanan seluruh barang ke pintu dari layout usulan 1 dan layout usulan 2 diatas, maka penulis akan melakukan perbandingan jarak total dari seluruh barang guna mencari jarak total terendah.

h. Perbandingan Jarak Tempuh Layout Usulan 1 dengan Layout Usulan 2

Setelah diperoleh hasil jarak tempuh material handling layout usulan 1 dan layout usulan 2, maka dilakukan perbandingan untuk mengetahui selisih antara layout usulan 1 dan layout usulan 2. Berikut merupakan perhitungan perbandingan:

Tabel 1 Perhitungan Perbandingan Layout Usulan 1 dengan Layout Usulan 2

\begin{tabular}{|c|c|c|c|}
\hline \multirow{2}{*}{$\mathrm{NO}$} & \multirow{2}{*}{ Nama Barang } & \multicolumn{2}{|c|}{$\begin{array}{l}\text { Jarak Barang } \\
\text { (Meter) }\end{array}$} \\
\hline & & $\begin{array}{c}\text { Layout } \\
\text { Usulan } \\
1 \\
\end{array}$ & $\begin{array}{c}\text { Layout } \\
\text { Usulan } \\
2 \\
\end{array}$ \\
\hline 1. & $\begin{array}{l}\text { NUTRITIONAL SHAKE MIX - } \\
\text { DUTCH CHOCOLATE }\end{array}$ & 7.1 & 7.1 \\
\hline 2. & $\begin{array}{c}\text { NUTRITIONAL SHAKE MIX - WILD } \\
\text { BERRY }\end{array}$ & 10.4 & 10.4 \\
\hline 3. & $\begin{array}{l}\text { NUTRITIONAL SHAKE MIX - } \\
\text { FRENCH VANILLA }\end{array}$ & 17.3 & 22.6 \\
\hline 4. & $\begin{array}{l}\text { HERBALIFE MIXED FIBER APPLE } \\
\text { FLAVOUR }\end{array}$ & 22.6 & 17.3 \\
\hline 5. & HAC MANGO FLAVOUR & 23.5 & 18.3 \\
\hline 6. & $\begin{array}{l}\text { HERBALIFE PERSONALIZED } \\
\text { PROTEIN POWDER }\end{array}$ & 23.8 & 21.4 \\
\hline 7. & $\begin{array}{l}\text { HERBALIFE F1 SHAKE MIX MINT } \\
\text { CHOCOLATE FLAVOUR }\end{array}$ & 25.2 & 25.2 \\
\hline
\end{tabular}




\begin{tabular}{|r|c|c|c|}
\hline 8. & $\begin{array}{c}\text { HAC MANDARIN ORANGE } \\
\text { FLAVOUR }\end{array}$ & 25.7 & 25.7 \\
\hline 9. & HERBAL ALOE CONCENTRATE & 27.5 & 27.5 \\
\hline 10. & $\begin{array}{c}\text { HERBALIFE F1 SHAKE MIX - } \\
\text { COOKIES N CREAM }\end{array}$ & 28.1 & 28.1 \\
\hline \multirow{2}{*}{ Total } & 211.2 & 203.6 \\
\hline
\end{tabular}

Perhitungan perbandingan dari total jarak seluruh barang ke pintu (I/O), jarak terkecil didapatkan oleh layout usulan 2. Jarak total layout usulan 2 adalah $203.6 \mathrm{~m}$ lebih kecil dibandingkan jarak total layout usulan 1 yang menempuh hingga $211.2 \mathrm{~m}$. Berdasarkan hasil perhitungan, penulis menggunakan layout usulan 2 untuk menyusun ulang layout gudang customer Herbalife. Berikut merupakan tabel perhitungan total layout usulan 2 menggunakan metode shared storage:

Tabel 2 Hasil Perhitungan akhir produk dengan Menggunakan Metode Shared Storage

\begin{tabular}{|c|c|c|c|c|c|}
\hline NO & Nama Barang & Nilai Throughput & Kebutuhan Ruang & Assignment & $\begin{array}{c}\text { Jarak Barang } \\
\text { (Meter) } \\
\end{array}$ \\
\hline 1 & \begin{tabular}{|c|} 
NUTRITIONAL SHAKE \\
MIX - FRENCH \\
VANILLA \\
\end{tabular} & 253 & 3 & 84 & 22.6 \\
\hline 2 & $\begin{array}{c}\text { NUTRITIONAL SHAKE } \\
\text { MIX - WILD BERRY }\end{array}$ & 281 & 3 & 94 & 10.4 \\
\hline 3 & $\begin{array}{c}\text { HERBALIFE F1 SHAKE } \\
\text { MIX MINT } \\
\text { CHOCOLATE } \\
\text { FLAVOUR } \\
\end{array}$ & 70 & 1 & 70 & 25.2 \\
\hline 4 & $\begin{array}{c}\text { HERBALIFE F1 SHAKE } \\
\text { MIX - COOKIES 'N } \\
\text { CREAM } \\
\end{array}$ & 105 & 2 & 53 & 28.1 \\
\hline 5 & $\begin{array}{c}\text { NUTRITIONAL SHAKE } \\
\text { MIX - DUTCH } \\
\text { CHOCOLATE } \\
\end{array}$ & 225 & 2 & 113 & 7.1 \\
\hline 6 & \begin{tabular}{|c|} 
HERBAL ALOE \\
CONCENTRATE \\
\end{tabular} & 61 & 1 & 61 & 27.5 \\
\hline 7 & $\begin{array}{c}\text { HAC MANGO } \\
\text { FLAVOUR }\end{array}$ & 74 & 1 & 74 & 18.3 \\
\hline 8 & $\begin{array}{c}\text { HAC MANDARIN } \\
\text { ORANGE FLAVOUR } \\
\end{array}$ & 69 & 1 & 69 & 25.7 \\
\hline 9 & $\begin{array}{c}\text { HERBALIFE } \\
\text { PERSONALIZED } \\
\text { PROTEIN POWDER } \\
\end{array}$ & 72 & 1 & 72 & 21.4 \\
\hline 10 & $\begin{array}{l}\text { HERBALIFE MIXED } \\
\text { FIBER APPLE } \\
\text { FLAVOUR } \\
\end{array}$ & 77 & 1 & 77 & 17.3 \\
\hline \multicolumn{5}{|c|}{ Total } & 203.6 \\
\hline
\end{tabular}

\section{KESIMPULAN}

Berdasarkan hasil penelitian dari permasalahan diarea gudang PT. Agility International customer Herbalife Indonesia yang belum optimal dan keadaan layout gudang setelah dilakukan perhitungan dengan metode shared storage, adalah sebagai berikut:

Metode shared storage dapat meminimumkan jarak pemindahan barang dari rak ke pintu (I/O), contoh seperti produk NUTRITIONAL SHAKE MIX - DUTCH CHOCOLATE dengan assignment 113 akan disimpan pada rak terdekat dengan pintu (I/O). Penempatan barang yang memiliki assignment tertinggi harus disimpan pada lokasi terdepan karena barang tersebut memiliki sifat fast moving, jarak rak barang dari pintu (I/O) berkisar $7.1 \mathrm{~m}$ setelah menggunakan metode shared storage. Dengan total jarak tempuh untuk seluruh produk yang ada digudang sekitar $203.6 \mathrm{~m}$.

\section{REFERENSI}

Heragu, S. Sunderesh, (2008). Facilities Design Third Edition. Taylor and Francis Group: United States.

Martono, R. (2015). "Manajemen Logistik Terintegrasi". Jakarta (ID): PPM.

Mulyati, E. dan Rachmi, R. (2012). "Redesain Layout untuk Meningkatkan Efisiensi Ruangan Gudang Tertutup: Studi Kasus PT Kaltim Industrial Estate". Politeknik Pos Indonesia, Bandung.

Setiadi, H. dan Iqbal, R. (2015). "Usulan Perencanaan Ulang Tata Letak Area Gudang Departemen Prasarana Kereta Api Menggunakan Metode Shared Storage di PT PINDAD (PERSERO)". Jurnal Logistik Bisnis, Vol.5. Politeknik Pos Indonesia, Bandung.

Sutisna, E. dan Irfan, M. (2015). "Analisis Perbaikan Tata Letak Gudang di PT PLN (Persero) APJ Bandung dengan Menggunakan Metode Shared Storage". Jurnal Logistik Bisnis, Vol.5. Politeknik Pos Indonesia, Bandung.

Zaenuri, M. (2015). "Evaluasi Perancangan Tata Letak Gudang Menggunakan Metode Shared Storage di PT. International Premium Pratama Surabaya". Jurnal Matrix Volume XV No. 2. Universitas Muhammadiyah Gresik, Jawa Timur. 